Reference Services Review, 2007, Vol. 35, No. 2, p. 322-330.

ISSN: 0090-7324

DOI: $10.1108 / 00907320710749227$

http://www.emeraldinsight.com/index.htm

http://www.emeraldinsight.com/journals.htm?issn=0090-7324\&volume=35\&issue $=2$

(c) 2007 Emerald Group Publishing Limited

\title{
The Johnson Center Library at George Mason University
}

\author{
Craig Gibson and Dorothy C. Lockaby George Mason University
}

\begin{abstract}
Purpose - This article sets out to discuss the Johnson Center Library, a gateway library in a multipurpose academic commons building first opened in 1996 at George Mason University, to identify the successes and limitations of this type of library concept, particularly in the context of more recent thinking about various types of information commons in libraries.

Design/methodology/approach - Descriptive information is provided about the architecture and layout of the library, its collections and services. The final part of the article uses a lessons learned approach to identify key experiential and consensus-based observations of library staff, library administrators, and others about the changing mission of the library over a decade (1996-2006).

Findings - The key findings of the authors focus on the need to revitalize the mission of the Johnson Center Library in order to move beyond the original gateway library concept. The findings also focus on the need to develop programmatic linkages with other stakeholders when a library facility is located in a multipurpose building; to create better architecturally defined spaces in order to enhance collection security; to design more flexible spaces that can be repurposed for changing needs in the networked environment.
\end{abstract}

Originality/value - The paper discusses a different approach to library services, a variation on the information commons concept, and shows how library-as-place is still very significant because of the blending of the social and the academic lives of students, when a library is part of a blended social and academic student center such as the Johnson Center itself.

\section{Introduction}

The concept of the information commons as an alternative to or blend of information technology services and library services has been evolving for many years, and the impetus behind its development has not just been philosophical but practical as well. First, the line of demarcation between the purpose of a computer lab and that of a reference department full of computers is increasingly blurred. Second, the foot traffic through the doors of academic libraries has been declining for years as students and faculty look elsewhere for much of their research, and partnering with other campus services had the potential to draw more students into the library. In their efforts to be flexible and grow in the direction of change, libraries have been trying newer models as a means to continue to provide state of the art services. By examining what has already been attempted and the ways in which the attempts were successful or failed in practice, much can be learned and applied to the future direction of these efforts.

\section{Origins of the Johnson Center Library}

During the past 15 years, many academic libraries have experimented with retrofitting their existing facilities to permit implementation of an information commons, or a similarly 
conceived "commons" concept, bringing together a suite of programs and services supporting research and information services, student life/support services, and other campus services. In 1995, a new building opened on the campus of George Mason University in Fairfax, Virginia, that did not need to be rearranged to fulfill such a mission because it had been conceived of and built as a combination student activity center, academic resource center, computer resource center, and library. The George W. Johnson Center represented the culmination of a plan that began when university leaders recognized in the late 1980s that George Mason University, a state-supported university located in the suburbs of Washington, DC, needed a focal space where its students, many of whom lived off-campus, could come together to mingle, learn, and form the heart of a growing institution. At the same time, more space was needed for the University Libraries, since the existing space at the Fenwick Library was approaching its capacity. Inspired by the vision of George W. Johnson, who was then the University's president, and of Charlene Hurt, the Director of Libraries during the planning and construction of the Johnson Center, the planners decided to serve multiple needs by designing one large, new facility that would sit, literally, at the center and highest point of the Fairfax campus, and would answer all of these purposes and more (Hurt, 2000, pp. 86-88). The potential to have the multiple uses of the building enhance each other in not entirely predictable ways was built into the facility. Hurt $(2000$, p. 87$)$ described the role of the new library that would be housed in the Johnson Center:

\footnotetext{
The first working hypothesis was that we would build an undergraduate library designed to support the emerging general education curriculum, with special emphasis on media and technology. Although we were sympathetic to many of the goals of undergraduate libraries, ... . many of us had also had experience with the problems such libraries faced, including the tendency to be viewed as second-class citizens in the library system. Nor did we like the linguistic distinction between "undergraduate" and "research" libraries, since we knew that many of our undergraduate students engaged in complex research. We were also convinced that technology would allow us to deliver information to multiple locations without duplication, thereby blurring the distinction between materials available in research libraries and those available elsewhere. What we really needed was a new entrance to the library system, one that could accommodate the technology we found hard to shoehorn into our present facility. We also needed student seating that was designed for different learning styles than those provided by our current library. And we needed space for collections, but not space dominated by its collections. So we conceived of the University Center Library [Johnson Center Library] as an electronic library with an undergraduate paper collection - a library for which we didn't have a name ("beginning library," "starter library," "media center," and "instructional resources center" were all speedily rejected), but for which we were beginning to have a mission
}

The Johnson Center encompasses 320,000 gross square feet (Hurt, 2000, p. 91) on four floors. At its center on the first floor are a circular campus information desk and a food court with a soaring three-story atrium rising above it, surmounted by large clerestory windows. The building also includes a cinema, a multimedia production lab, multiple computer labs, the University's admissions office, a bank, a credit union, an art gallery, a post office, the alumni office, two restaurants, the campus bookstore, the campus computer store, a convenience store, the campus radio station, a dance studio, a large multi-purpose auditorium, a variety of smaller meeting rooms, and several student-centered multicultural resource centers. In addition to all of these centers of activity, about one third of the building is devoted to the Johnson Center Library (Kifer, 2005, p. 47), which is integrated into the life of the building in a way that makes it hard to tell where the library ends and the other activities in the building begin.

The Johnson Center Library is composed of two distinct areas within the building. Along one side of the building on floors two and three, there are open stacks holding a circulating book collection of just over 100,000 volumes (Kifer, 2005, p. 52). The rows of book stacks are separated 
from the atrium overlooking the food court below by nothing more than a walkway, some furniture, and a railing. Study carrels are arranged between the rows of shelving, and there are no walls or doors between the library stacks and the rest of the building. Between the book stacks and the outer walls are large, open study areas and lounges, filled with group study tables as well as comfortable sofas and chairs. The outer walls feature large expanses of glass, and the areas along the outside of the building are bright, comfortable, and welcoming. They are also somewhat quieter and more conducive to studying than other areas of the building because the book stacks create a buffer between the study areas and the food court below, but they are not as quiet as a traditional academic library. For a truly quiet study area, patrons use one of the 24 group study rooms distributed around the open stack areas, or they travel a few hundred yards northeast of the Johnson Center to the Fenwick Library, where they find a more traditional library environment. Food and beverages are permitted in all areas of the Johnson Center, and students can be seen eating in the library areas as often as in the food court.

The second part of the Johnson Center Library is an enclosed two-story area right off of the food court, with a single entrance that is controlled by a standard library security gate. The controlled library has large windows that look on the food court, and the windows display neon signs that advertise that the library provides books, CDs, videos, and internet access. Inside the library, directly opposite the door, is a large circulation and reserves service desk, and toward the right side of the first floor is a reference desk, with a small print reference collection nearby. Desktop computers are clustered on both the first and second floors for patron access to the library catalog, licensed electronic databases, and the internet, and there is a central pay-per-print station on each floor. The Library contains all of the media collections for the Fairfax campus, roughly 33,000 items in a variety of formats, and these, along with the audiovisual equipment necessary to use them, are kept secure within the enclosed first floor space. The Johnson Center Library's first floor enclosed space is also the home to the musical score collection and the music reference collection. The Johnson Center Library processes and manages all of the reserves for the Fairfax campus, including print, electronic, and media formats. The second floor of the controlled space holds a computer-equipped library instruction classroom, a K-12 curriculum collection, the University's copyright office, and the administrative offices for the Johnson Center Library, as well as study carrels and tables. Public access to the second floor enclosed space is only possible through the first floor enclosed space, although windows that look out upon the food court and atrium span the length of the area.

\section{The Johnson Center Library today}

Some of the ideas built into the Johnson Center have stood the test of time better than others, and as the building and university have evolved, the Johnson Center Library has gradually changed as well. The open stacks area of the library is one concept that has been a resounding success in most respects. The area fosters both planned and impromptu gatherings of students in ways. that are not only in keeping with the building's original intent (Geraghty, 1996, p. A39) but probably exceed the most optimistic hopes of its designers. When it was built, the Johnson Center was heavily equipped with electrical outlets and Internet connections, including pre-wired tables and study carrels, to facilitate and encourage the use of computers in the facility (Hurt, 2000, pp. 98-99). Today, the building is fully covered with a wireless network, making it even more flexible for users of laptop computers than it was when new. When classes are in session, the Johnson Center is open until 2 a.m., including the open stacks areas of the building (the enclosed part of the library closes at midnight), and the study areas are full of students studying, eating, working in 
groups, relaxing in groups, reading, playing cards, discussing assignments - in short, doing all of the things they might do in their living rooms if all of their friends, classmates, professors, and acquaintances could come to their homes. On weekdays, the food court is so crowded as to be difficult to walk across, and the crowd spills out into the library study areas around the perimeter of the building. Because of the proximity of all of the services and resources within the walls of the building, students and faculty wind up there for any number of reasons, and they encounter others with whom they need or want to interact. Often, this interaction takes the form of a sit-down session in one of the alcoves or study rooms of the Johnson Center Library.

Library reference and consultation services are accessed heavily at the Johnson Center in an era when traditional academic libraries are seeing reduced foot traffic and reduced face-to-face reference activity. It appears that some students, who perhaps would not go out of their way to stop into a separate library building, find it convenient to stop in and ask for assistance with a research question while they are in the building for some other purpose. The Johnson Center Library offers basic workshops on library skills and use of citation management software on a drop-in basis, and the reference desk is easily visible from the food court and atrium through the wide windows, so students are encouraged to stop in and examine the media collection or ask a question at one of the service points. Gate counts on the enclosed portion of the library demonstrate that people do drop in: close to a half million people enter the controlled library space each year. The energy in the building is almost palpable, and, as a place to do schoolwork or just gather to exchange greetings and ideas over some food, the library is a living part of the mix. The blending of the academic library into the social environment of the campus is seamless at the Johnson Center.

Although visitors often wonder aloud whether the open collection has been depleted by wholesale thefts of books, and some faculty are convinced that the materials are too vulnerable, this has not proven to be a serious problem except in certain specific subsets of the collection, and adjustment of collection development activities has reduced theft losses to a rate comparable with most other academic libraries. The original collection guidelines emphasized foundation books, undergraduate-level materials, technology-related books, and resources that would support the multicultural and diversity-related mission and flavor of George Mason University (Hurt et al., 1995, p. 488). As time passed, a few problem areas became apparent. In keeping with the original emphasis on technology at the Johnson Center, many books in the subject areas of computing and information technology had been selected for inclusion in the Library's collection. Unfortunately, books in those areas showed a highly disproportionate loss rate. The problem was easily solved by putting some books on Permanent Reserve at the Johnson Center, leaving selected books on the Johnson Center shelves, and placing others in the Fenwick Library instead of in the Johnson Center (Kifer, 2005, pp. 53-54). By giving slightly more thought to the placement of this subject area, the problem was substantially solved. Purchasing guidelines also discourage the placement of expensive books in any subject area into the open stacks, which seems to be an obvious decision. In 1998, the Fenwick Library had nearly reached its capacity, so two discrete collections, music and education, were selected to be moved in their entirety to the Johnson Center. Although this move changed the nature of the collections by adding graduate-level resources to what had previously been an undergraduate-focused collection, it made sense in relation to the other collections housed in the building (Kifer, 2005, p. 53). Because all of the audio-visual media are housed at the Johnson Center, moving the music collection there created better proximity of related materials. A performing arts student can obtain books, scores, and audio resources related to the same composer all in the same place, and perhaps also obtain the assistance of the performing arts liaison librarian, whose office is located in the Johnson Center Library. 
The long-term success of the controlled access portion of the library has been more mixed than that of the open area, primarily because the evolving nature of services and collections requires maximum flexibility, and the space has not proven to be very flexible. As mentioned above, the enclosed portion of the library contains extensive media collections as well as general reference, music reference, and musical scores collections, so it is important to control that area in order to safeguard the materials. However, the music and media collections have grown substantially over the past decade, along with the associated assortment of audio-visual equipment, and the way that the space is broken up on two floors has made it difficult to configure the space so that it works well for both the staff and the patrons. For example, the original building lay-out had the circulation desk on the first floor of the enclosed space and the reference desk on the second. The idea that inspired this arrangement was that the second floor would be a "teaching floor" (Hurt, 2000, p. 102), but the arrangement proved to be confusing to patrons, and it necessitated their going through the first floor to get to the service point on the second floor in what is essentially a cul-de-sac. Eventually, the reference desk was moved to the first floor, which improved its visibility and interactivity considerably, but which left the enclosed second floor with no service point and no collections except the curriculum collection. Finding a way to exploit the underutilized and relatively inaccessible space on the second floor has been a challenge, made more urgent by the congestion on the first floor. At present, consideration is being given to creating a media center in the second floor space and moving all associated materials and equipment to that area, but the nature of the lay-out of stairs and other relatively immovable features limits the possibilities.

\section{Lessons learned from the Johnson Center Library}

As a pioneering example of the "library as place" within a multipurpose building, the Johnson Center offers telling lessons. Planning for the building itself necessarily reflected the thinking of the early 1990s, with the "gateway" library as an implicit guiding concept. This concept saw the library as having a crucial role as a physical portal for new users to the array of information resources, either on campus or in the larger information world. According to Wilson, the values and priorities of the "gateway" library centered on access to both print and digital resources, education, outreach, creating linkages between the novice researcher and the wider world of information, and forging of connections and partnerships and relationships within the community (Wilson, 1999, pp. 24-25). At George Mason, the initial impetus for the Johnson Center Library was to create those linkages for the beginning researcher from an educational vantage point both within the Johnson Center itself and for the entire university. Particular partnerships were forged with an interdisciplinary undergraduate program, New Century College, originally co-located in the Johnson Center building, and with some offices and initiatives either located in the building or elsewhere on campus: the Freshman Center and the Center for Teaching Excellence, located in the Johnson Center; and the Writing Center, located elsewhere on campus but on occasion collaborating on library staff in the Johnson Center to offer writing and research clinics in the Johnson Center itself. The range of partnerships developed illustrates the possibilities for a library located in a multi-purpose building.

Our experience with the Johnson Center Library has shown that the gateway library concept itself was in part overtaken by new academic programming, library space reprogramming, and technological changes throughout the university. For example, New Century College, originally an independent academic unit, became part of the College of Arts and Sciences, and was moved to another building. Space pressures in the Fenwick Library resulted in the moving of the 
music and education collections to the Johnson Center Library in 1998, changing the character of the library itself from an introductory "portal" or gateway library to more of a mixed gateway-and-subject-specific facility. Perhaps most important, the networked digital environment evolved rapidly, with databases, electronic journals, electronic books, and other resources added to the Libraries' holdings at an exponential rate after 1996, and continuing into the present (with the migration of CD-ROM-based databases to the web occurring during this same period). These resources are now available from networked workstations in all academic computing labs on campus, in wired student residence halls, in student union buildings and electronic classrooms elsewhere, and of course, through wireless environments everywhere on campus. The cumulative effect of these varied changes has meant that the original mission of the Johnson Center Library is now less clear.

The question has become, what remains of the original gateway concept, when networked digital resources supplant (or become the totality of information resources in the minds of many students) the "library as place" within a physical, multipurpose building? In effect, the "gateway" became diffused in the minds of library users in a variety of ways. They use popular search engines and tools (Google, Yahoo) to acquire information from the "surface web," but still use the library as a study space or a space for collaborative projects with friends. The gateway concept in part is taken over by the library web site itself, which becomes the entry point or portal for library services; by course manage systems such as WebCT or Blackboard; and by electronic reserves systems; or by a range of other digital entry points, sponsored by the library or by other information providers. This diffused virtual "gateway" means that the physical identity of the gateway library, clearly defined in the early 1990s, is now uncertain. However, the original "gateway" concept survives in some important sense because of the blending of the social and the academic dimensions of student behavior. Students find the Johnson Center Library itself a very helpful environment for studying alone or with friends, working on collaborative projects, getting quick answers to questions from reference and access services staff, and taking advantage of other programming and services in proximity - computer labs, food, bank, post office, and entertainment. The unplanned and fortuitous learning that occurs in the building as a whole is palpable and powerful.

However, we have learned the following, based on ten years of experience with the Johnson Center Library and its role in the Johnson Center building:

- Programmatic linkages and relationships need to be thought about early from the Library's vantage point, when it is co-located with other service units or programs in an academic multipurpose building. Placing likely collaborators in proximity and hoping that partnerships will flourish may or may not work; the planning process for the building itself should also include planning for intra-institutional partnerships, collaborations, and synergies. Models and best practices need to be developed for such collaborations, reward and incentives need to be provided, and, perhaps most helpful in a student-centered learning environment, students themselves should be involved even more integrally in the planning process.

- Architectural planning should provide for maximum flexibility to allow for changes in technology, and students' information-gathering behaviors, so that flexible repurposing of space can occur over time. The controlled part of the Johnson Center Library space is quite inflexible in its furnishings, electrical 
systems, and configuration. Nimble programmatic changes in that library have therefore been difficult to accomplish

- Special formats such as media materials, when part of a limited, controlled space such as that of the "closed" part of the Johnson Center Library, present special challenges because of space limitations, loss rates of the materials themselves, the need to house a wide variety of viewing/listening stations, and accessibility issues for the disabled in a constrained space with little flexibility. Media collections in general can be thought of in concert with subject-based (e.g. music, film studies) collections or as general-purpose collections serving the entire academic community. Centralizing media collections without making them available digitally to designated workstations, or through such technologies as streaming video, create a large infrastructure and service challenge.

- Collection security must be provided for in a more thoughtful way. Even though the Johnson Center collections in the "open" (uncontrolled) library space have seen theft and loss rates not appreciably greater than loss rates in other academic libraries, perceptions developed early that "books were walking out the door"; perceptions are very powerful and often difficult to overcome. Housing physical collections in more controlled spaces rather than in open, multi-purpose spaces would be a likely solution for this challenge.

- A library located in a multi-purpose academic commons should capitalize on the opportunities available in the student-led and student-driven learning environment in a more concerted way, and use the library itself as a locus of research, experimentation, and risk-taking - to learn what students' research behaviors are (even through very informal, unstructured conversations with students, and possibly through more research-based protocols), what their preferences are, and what they like and do not like about library resources, services, and outreach from the library. We have seen the potential for such experimentation and creativity, but it has not been realized to this point. The diffusion of the gateway concept into virtual channels, the loss of clear programmatic ties with such programs as New Century College, and the undefined mission of the library itself in the complex welter of an information-rich academic commons such as the larger Johnson Center building itself, has resulted in variety of experimentation that has yield only partial success.

\section{The future of the Johnson Center Library}

In summary, the Johnson Center Library affords an invaluable case study of library services and programmatic partnerships located in a multi-purpose academic building. The concept behind the Johnson Center itself reveals the thinking of its time - the early to mid-1990s in creating synergistic environments that would allow blending of the social and academic lives of students, while also achieving cost savings in co-locating many campus services in the same building, rather than constructing separate student services in physically separate buildings. The enormous success of the Johnson Center building itself grows out of the student-created learning environment; the building has evolved to bring together the entire university community in an 
academic commons which features student peer group interactions in diverse, highly situational ways. The Johnson Center Library itself has remained open to experimentation during the first ten years of its history, and is considered by all the units in the building to be an integral partner in planning services and programming throughout the building. The implicit learning commons concept behind the Johnson Center Library has remained only partly realized, however, and, with some exceptions, programmatic partnerships between the Library and other building units have not always sustained themselves in a way that would show deep impact. At this point, the physical configuration and academic functions of the Johnson Center Library are under review, and the University has retained a noted architectural firm to plan an expansion of the Fenwick Library, which necessarily involves discussions of the future of the Johnson Center Library. Ten years of some successful, and some not so successful, collaborative experiences of the Johnson Center Library with other stakeholders in this still compelling building should afford library administrators, architects, and librarians on the front lines interacting with students, some powerful lessons about the need for deep collaboration, thoughtful planning, and ongoing experimentation. The Johnson Center Library has shown part of what is possible in the life of a multipurpose building; its future holds promise for showing even greater innovation.

\section{References}

Geraghty, M. (1996), "A new kind of student union aims to meet academic and social needs. George Mason facility includes a food court, a library, classrooms, and a dance studio", The Chronicle of Higher Education, Vol. 43, pp. A39-A40.

Hurt, C. (2000), "The Johnson Center Library at George Mason University”, in Webb, T.D. (Ed.), Building Libraries for the 21st Century: The Shape of Information, McFarland, Jefferson, NC, pp. 83-104.

Hurt, C.S., Rein, L.O., Walsh, J.C. and Wu, A.C. (1995), "Collection development strategies for a university center library", College \& Research Libraries, Vol. 56, pp. 487-95.

Kifer, R.E. (2005), “'Real' university libraries don't have neon lights”, in Cleyle, S.E. and Gillis, L.N. (Eds), Last One out Turn off the Lights: Is This the Future of American and Canadian Libraries?, Scarecrow Press, Lanham, MD.

Wilson, L. (1999), "The gateway library: rethinking undergraduate services", in Montanelli, D.S. and Stenstrom, P.F. (Eds), People Come First: User-Centered Academic Library Service, American Library Association, Chicago, IL, pp. 13-44. 